DOI https://doi.org/10.30525/978-9934-26-111-4-50

\title{
ЗАСТОСУВАННЯ УДОБРЮВАЛЬНОГО ЗРОШЕННЯ КУКУРУДЗИ В УМОВАХ ПІВНІЧНОГО СТЕПУ УКРАЇНИ
}

\author{
Онопрієнко Д. М. \\ кандидат сільськогосподарських наук, \\ професор кафедри цивільної інженерії, \\ технологій будівництва і захисту довкілля \\ Дніпровський державний аграрно-економічний університет \\ м. Дніпро, Украӥна
}

П'ятий рік поспіль в загальному обсязі виробництва зернових культур в Україні частка кукурудзи становить близько $40 \%$, а врожайність зерна досягла рекордних 35,9 млн. тон порівняно з 12 млн. тон десять років тому. За ці роки Україна стала вагомим світовим експортером кукурудзи, і надійним постачальником якісного зерна. Основними труднощами, з якими зіткнулися аграрії в останні роки при вирощуванні кукурудзи були кліматичні, а саме брак продуктивної вологи в грунті не дав можливості для нормального формування та наливу зерна.

Важливість та актуальність проблеми забезпечення вологою i поживними речовинами посівів кукурудзи і ступінь їх впливу на величину врожайності і якості зерна не викликає сумнівів. Правильно використовуючи мінеральні добрива, можна забезпечити збалансоване живлення рослин, не допускати дефіциту або надлишку елементів живлення, досягти не тільки високої продуктивності, але і поліпшення якісних показників $[1$, p. 8]. Великого значення при цьому надають з'ясуванню впливу живлення і зволоження на розвиток рослин i формування врожаю [2, p. 211].

Традиційна технологія внесення мінеральних добрив в зрошуваному землеробстві була механічно перенесена із неполивного землеробства, де за допомогою причіпних або навісних відцентрових розкидачів добрива розподіляють по поверхні поля з подальшим загортанням у грунт 3 допомогою оранки, культивації, або боронування [3, p. 230]. Нерівномірність внесення добрив (навіть 3 непорушеними властивостями) деякими розкидачами досягала $30 \%$, що викликало значні недобори врожаю [4, p. 57].

Нерівномірне розкидання по поверхні грунту, особливо надмірної кількості добрив, призводять до нераціонального використання, 214 
негативних наслідків не тільки для рослин, але і для грунту (надлишок поживних речовин в одних і відсутність в інших місцях, нітратне забруднення, тощо), які часто не вдається виправити [5, p. 198].

Саме 3 цих причин у системі інтенсивної технології вирощування кукурудзи все більше застосовують прогресивний спосіб внесення мінеральних добрив разом 3 поливною водою, що отримав назву «фертигація», або удобрювальне зрошення [6, р. 158]. Внесення добрив одночасно 3 поливом створює можливість оптимізації постачання рослин вологою i легкодоступними формами поживних речовин протягом усього вегетаційного періоду. Фертигація докорінно вирішує проблему рівномірного розподілу по площі добрив в активному шарі грунту до рівня рівномірності розподілу поливної води, що оцінюється коефіцієнтом варіації не вище 20 \%. Крім цього, важливою перевагою цього способу є можливість подачі поживних речовин 3 добрив невеликими дозами протягом вегетаційного періоду, коли рослини його найбільше потребують, без пошкодження листя, як механічно так i через хімічні опіки [7, с. 58].

Метою наших досліджень було вивчити вплив різних способів внесення твердих i рідких мінеральних добрив на ефективність агротехнології виробництва зерна кукурудзи в умовах зрошення північного Степу України.

Польові досліди 3 вивчення впливу різних способів внесення мінеральних добрив на урожайність зерна кукурудзи проводили на полях у селянському фермерському господарстві «AIST» Синельниківського району Дніпропетровської області протягом 2016-2018 років.

На дослідних ділянках вивчали чорноземи звичайні малогумусні важкосуглинкові з такими основними характеристиками: об'ємна маса шару грунту 0-70 см складає 1,96 г/ $\mathrm{cm}^{3}$, найменша вологоємкість (НВ) $24,1 \%$, діапазон активної вологи в гумусованій частині профілю грунтів складає 25,79-30,41 \%, запаси продуктивної вологи в шарі 0-50 та 0-70 см відповідно - 2420 та $3550 \mathrm{~m}^{3} /$ га (за найменшої вологоємності грунту). Потужність гумусованого шару становить 70-75 см, а вміст органічної речовини в орному шарі грунту за Тюріним - 2,6-3,0 \%. Нітратного азоту $\mathrm{N}_{-} \mathrm{NO}_{3}$ (за Кравковим) в 1 кг сухого грунту містилось 8,2-20,6, рухомого фосфору $\mathrm{P}_{2} \mathrm{O}_{5}$ (за Чириковим) - 134-145, обмінного калію $\mathrm{K}_{2} \mathrm{O}$ (за Чириковим) - 175-188 мг/кг грунту. Загальна площа поля 120 га, посівна площа дослідних ділянок 16,2 га, а облікова площа 12,5 га, повторність - чотириразова.

Погодні умови за роки досліджень були в цілому сприятливими для вирощування кукурудзи в умовах зрошення. За вегетаційний період 
(травень - вересень) 2016 року випало 373 мм дощів, у 2017 р. 177 мм, а у 2018 році - 157 мм.

У дослідах висівали середньостиглий гібрид кукурудзи ДКС 4351 (ФАО 350) густотою 80 тис. рослин на гектарі. Вивчали норми мінеральних добрив, розраховані для одержання врожаю зерна 12 т/га. Передбачали також варіант без добрив і без поливу. Технологія вирощування кукурудзи була загальноприйнятою для цієї культури в зоні північного Степу України. Поливи проводили широкозахватною дощувальною машиною фронтальної дії виробництва фірми Reinke (USA, Sistem Serial No: 1212-54432-2065/2060 MAXI). Ширина поливу машиною 375,2 м, з витратою води 113 л/с. Розчин мінеральних добрив дозували в поливну воду спеціальним гідропідживлювачем фірми MILTON ROY (USA, Manual No: 53873) з максимальною продуктивністю 110 галонів за годину, або 416 літрів за годину. Поливний режим передбачав підтримання вологості грунту в активному шарі не нижче 70-80\% НВ. Зрошувальна норма становила у 2016 р. $2100 \mathrm{~m}^{3} /$ га, у 2017 р. - 2400, а у 2018 р. $-2500 \mathrm{~m}^{3} /$ га.

Із твердих мінеральних добрив застосовували сечовину (карбамід), амофос і калійні добрива (компанія Kalium Makosh, Польща). Iз рідких азотних добрив використовували КАС-32. Амофос вносили у розрахункових дозах по ділянках під оранку восени, азотні - відповідно до програми досліджень під культивацію і з поливною водою, а калійні добрива під культивацію навесні.

Дози мінеральних добрив для одержання запланованого врожаю зерна кукурудзи 12 т/га обчислювали балансовим методом 3 урахуванням вмісту основних елементів живлення в орному шарі грунту. Розрахункові дози становили $\mathrm{N}_{200} \mathrm{P}_{90} \mathrm{~K}_{60}$

3 метою вивчення ефективності внесення твердих і рідких форм мінеральних добрив 3 поливною водою, в порівнянні $з$ традиційним розкидним способом і визначення оптимальних параметрів фертигації при вирощуванні кукурудзи на зерно були розроблені різні варіанти. Технологічні схеми внесення мінеральних добрив були такими:

I - під культивацію перед сівбою (карбамід) врозкид повною нормою $\mathrm{N}_{200}$ i під осінню оранку (амофос) нормою $\mathrm{P}_{90}$ при зрошенні;

II - під культивацію перед сівбою (КАС-32) нормою $\mathrm{N}_{200}$ самохідним оприскувачем і під осінню оранку (амофос) нормою $\mathrm{P}_{90}$ при зрошенні;

III - роздрібно 3 поливною водою повною нормою $\mathrm{N}_{200}$ (карбамід) під час проведення вегетаційних поливів (фертигація); 
IV - роздрібно з поливною водою повною нормою $\mathrm{N}_{200}$ (КАС-32) під час проведення вегетаційних поливів (фертигація).

Також в дослідах передбачали контрольний варіант без добрив. За всіма наведеними технологічними схемами рідкі калійні добрива нормою $\mathrm{K}_{60}$ вносили самохідним оприскувачем під передпосівну культивацію

Наведені в таблиці 1 дані однозначно вказують на те, що фактична урожайність зерна гібрида кукурудзи ДКС 4351 за внесення мінеральних добрив з поливною водою була вищою, ніж за традиційної технології їх внесення.

Максимальну урожайність зерна кукурудзи, в середньому за три роки, одержали за внесення карбаміду нормою $\mathrm{N}_{200} 3$ поливною водою під час вегетаційних поливів - 12,9 т/га, а за внесення КАС-32 нормою $\mathrm{N}_{200} 3$ поливною водою під час вегетаційних поливів урожайність зерна була меншою всього на 0,2 т/га (табл. 1).

Таблиця 1

Вплив способів внесення мінеральних добрив на урожайність зерна гібрида кукурудзи ДКС 4351, т/га

\begin{tabular}{|c|c|c|c|c|}
\hline $\begin{array}{c}\text { Спосіб внесення мінеральних } \\
\text { добрив }\end{array}$ & 2016 p. & 2017 p. & 2018 p. & $\begin{array}{c}\text { Середне за } \\
\text { три роки }\end{array}$ \\
\hline Без добрив (контроль) & 4,8 & 5,2 & 5,7 & 5,3 \\
\hline $\begin{array}{c}\text { норма } \mathrm{N}_{200} \text { карбамід врозкид по } \\
\text { поверхні грунту під } \\
\text { культивацію навесні }\end{array}$ & 12,3 & 12,4 & 12,7 & 12,4 \\
\hline $\begin{array}{c}\text { норма } \mathrm{N}_{200} \text { KAC-32 } \\
\text { оприскувачем по поверхні } \\
\text { грунту під культивацію навесні }\end{array}$ & 12,4 & 12,5 & 12,7 & 12,5 \\
\hline $\begin{array}{c}\text { норма } \mathrm{N}_{200} \text { карбамід роздрібно } \\
3 \text { поливною водою }\end{array}$ & 12,8 & 12,9 & 13,0 & 12,9 \\
\hline $\begin{array}{c}\text { норма } \mathrm{N}_{200} \text { KАС-32 роздрібно } 3 \\
\text { поливною водою }\end{array}$ & 12,8 & 12,7 & 12,8 & 12,7 \\
\hline
\end{tabular}

$\mathrm{HIP}_{05}$ для способів і термінів внесення добрив $-0,24$ т/га

При оцінюванні будь-якого технологічного заходу важливо враховувати його вплив не тільки на величину врожаю, але i на його споживчі якості. При зрошенні разом із збільшенням урожаїв, часто спостерігається погіршення якості зерна, а саме зменшення білка. У таблиці 2 наводяться результати визначення білка, жирів, крохмалю i 
клітковини які показали, що при внесенні різними способами розрахункових доз мінеральних добрив вміст білка у зерні кукурудзи зростав, але суттєво не впливав на вміст крохмалю, жиру і клітковини в зерні. При фертигації карбамідом вміст білка в зерні зростав на $0,54 \%$ порівняно 3 варіантом, де його вносили врозкид поверхнево, а фертигація КАС-32 забезпечила зростання білка в зерні на на $0,12 \%$ порівняно з варіантом, де його вносили оприскувачем.

Таблиця 2

Якість зерна гібрида кукурудзи ДКС 4351 залежно від способів внесення азотних добрив (середнс за 2016-2018 рр.)

\begin{tabular}{|c|c|c|c|c|}
\hline \multirow{2}{*}{$\begin{array}{c}\text { Спосіб внесення } \\
\text { азотних добрив } \\
\text { і доза }\end{array}$} & \multicolumn{4}{|c|}{ Вміст у зерні, \% } \\
\cline { 2 - 5 } & $\begin{array}{c}\text { сирий } \\
\text { білок }\end{array}$ & жир & крохмаль & клітковина \\
\hline $\begin{array}{c}\text { Без добрив } \\
\text { (контроль) }\end{array}$ & 7,11 & 3,28 & 61,8 & 2,9 \\
\hline $\begin{array}{c}\text { норма } \mathrm{N}_{200} \text { карбамід } \\
\text { врозкид під } \\
\text { культивацію навесні }\end{array}$ & 7,61 & 3,52 & 62,9 & 2,9 \\
\hline $\begin{array}{c}\text { норма } \mathrm{N}_{200} \text { КАС-32 } \\
\text { оприскувачем під } \\
\text { культивацію навесні }\end{array}$ & 7,83 & 3,58 & 62,7 & 2,9 \\
\hline $\begin{array}{c}\text { норма } \mathrm{N}_{200} \text { карбамід } \\
\text { роздрібно } \\
\text { з поливною водою }\end{array}$ & 8,15 & 3,12 & 63,1 & 3,0 \\
\hline $\begin{array}{c}\text { норма } \mathrm{N}_{200} \text { КАС-32 } \\
\text { роздрібно } \\
\text { з поливною водою }\end{array}$ & 7,95 & 3,47 & 63,2 & 3,0 \\
\hline
\end{tabular}

За результатами проведених трирічних досліджень було встановлено високу ефективність удобрювального зрошення (фертигація) на чорноземах звичайних при виробництві зерна гібрида кукурудзи ДКС 4351, взамін традиційних способів унесення мінеральних добрив.

Максимальну урожайність зерна кукурудзи одержали за внесення карбаміду нормою $\mathrm{N}_{200} 3$ поливною водою під час вегетаційних поливів $(12,9$ т/га), а за внесення КАС-32 тією ж нормою з поливною водою урожайність зерна була дещо меншою і становила 12,7 т/га, тобто приріст урожаю порівняно 3 контролем становив 7,4-7,6 т/га. На 
ділянках де добрива не вносили (контроль) урожайність зерна становила всього 5,3 т/га.

Результати досліджень свідчать що поєднання поливів із внесенням мінеральних добрив (фертигація) $є$ ефективним шляхом заощадження енергетичних і матеріальних ресурсів, підвищення врожайності і якості врожаю зерна кукурудзи, охорони грунту від деградації.

\section{Література:}

1. Barlog P., Frckowiak-Pawlak K. Effect of Mineral Fertilization on Yield of Maize Cultivars Differing in Maturity Scale. Acta Sci. Pol. Agricultura. 2008. № 7. P. 5-17.

2. Lamm F.R., Schlergel A.J., Clark G.A. Development of a best management practice for nitrogen fertigation of corn using SDI. Applied engineering in agriculture. American society of agricultural engineers. 2004. Vol. 20. P. 211-220.

3. Selbie D.R., Buckthought L.E., Shepherd M.A. The challenge of the urine patch for managing nitrogen in grazed pasture systems. Advances in Agronomy. 2015. Vol. 129. P. 229-292.

4. Anna Biau, Francisca Santiveri, Iker Mijangos, Jaume Lloveras. The impact of organic and mineral fertilizers on soil quality parameters and the productivity of irrigated maize crops in semiarid regions. European Journal of Soil Biology. 2012. Vol. 53. P. 56-61. doi.org/10.1016/ j.ejsobi.2012.08.008

5. Mohammad Esmaeil Asadi, Roberto Clemente, Ashim Das Gupta, Rainer Loof, Gunner K. Hansen. Impacts of fertigation via sprinkler irrigation on nitrate leaching and corn yield in an acid-sulphate soil in Thailand. Agricultural Water Management. 2002. Vol. 52(3). P. 197-213. doi: 10.1016/S0378-3774(01)00136-6

6. Onopriienko D., Kharytonov M. The effects of irrigation and nitrogen application rates on yield and quality of corn in the Steppe zone of Ukraine. Agriculture \& Forestry. 2019. Vol. 65. P. 157-164. DOI: 10.17707/ AgricultForest.65.1.16

7. Ківер В.Х., Онопрієнко Д.М. Енергозаощадлива агротехнологія виробництва зерна кукурудзи на зрошуваних землях. Вісник аграрної науки. 2019. № 4. с. 74-81. doi: 10.31073/agrovisnyk 201904-11 